\title{
Influence of Using Games on Learning English Vocabulary by Syrian Refugee Students in Jordan
}

\author{
Yousef F. Bader (Corresponding author) \\ Department of English Language and Literature, Yarmouk University \\ Irbid, Jordan \\ E-mail: yfbader@yu.edu.jo
}

Diana Abdel Razzaq

Department of English Language and Literature, Yarmouk University

Irbid, Jordan

Received: September 2, 2021

Accepted: October 4, 2021

Published: October 7, 2021

doi:10.5296/ijl.v13i5.19074

URL: https://doi.org/10.5296/ijl.v13i5.19074

\begin{abstract}
This study examines the influence of using games on learning English vocabulary and attempts to reveal the significant differences between using games and using traditional methods in learning English vocabulary among sixth grade Syrian students in Jordan. For these purposes, a group of thirty female participants were divided into two groups, each one consisting of fifteen participants. The first group was exposed to forty minutes of ten vocabulary games, three days a week for four months. The second group was exposed to traditional methods in learning vocabulary for forty minutes a day, three days a week for four months. The latter method depended on the teacher's role in giving words and their meaning, writing them on the board and asking students to memorize them. The researchers selected certain vocabulary games according to several criteria to be given to children. A pretest was conducted for each group to compare its results with the posttest results. The results of the comparison showed a significant increase in participants' accomplishment by using vocabulary games. This suggests that vocabulary games can be used as an effective tool in learning English vocabulary.
\end{abstract}

Keywords: Vocabulary, Vocabulary games, Traditional methods, Learning English 


\section{Introduction}

Learning a foreign Language like English is important, especially in a country like Jordan, and learning new vocabulary is an essential part of the learning stages. For many years in the past, linguists considered phonological structure and grammatical rules more important than learning vocabulary, despite the fact that having sufficient vocabulary enables students to use this language effectively (Wilkins, 972). Students of a foreign language have to learn vocabulary which is an important building block of that language. When learners learn vocabulary, they become able to communicate by using the target language (Troik, 1984). There are many important rules in learning any foreign language vocabularies. For example, learners have to know the structure, meaning and usage of a word in different contexts. In addition, learners should know how to pronounce, how to spell and how to write these new vocabularies (Wallace, 1982).

Learning vocabulary is considered as an important and effortful process, so instructors should care about teaching their students new vocabulary, and students should concentrate on how to use these new vocabularies because ignoring any word aspect, its meaning or spelling affects negatively the vocabulary development of the students (Sweet, 1982). Teachers are responsible about fostering children's academic performance, especially their foreign language proficiency. Therefore, specific learning activities are implemented in classrooms. According to Hatch and Brown (1995), there are many types of approaches and techniques that can be used to teach vocabulary, but teachers should choose the best approach according to their students' ability and their circumstances. There are many studies that were conducted on new learners of foreign language field.

Huyen and Nga (2003) and Uberman (1998) indicated that students dislike traditional methods of learning vocabulary. The first two authors suggested that students prefer to learn language in a relaxed environment. For example, games are one of the most effective preferable methods of learning (Freeman, 1989). So, teachers are required to find interesting and attractive ways to motivate their students' skills. The present paper aims at revealing the effect of using games technique on vocabulary learning by a group of Syrian refugee students at a Secondary School in Ramtha, a city in north Jordan close to the Syrian border. The games used include some of the following:

Crossword: It is a kind of words puzzle. Each player forms words down and cross to fill the puzzle (Darfilal, 2015).

Scrabble: in this game, each player takes a number of separate letters and places them on a board to make a word (Darfilal, 2015).

Taboo: In this game, one player has to get the others to guess a certain word using verbal explanation or gestures. A set time period is defined for the person to explain (Darfilal, 2015).

Crazy eraser: The teacher rubs the board erasing some words, and students have to reconstruct what was written earlier (Darfilal, 2015). 
Hot Potatoes: The class is divided into group A and B with both teams sitting on the opposite sides of the classroom. Two chairs are placed in the middle of the class so that whoever sits on the chair will face her/his team and the board must be behind them. Then, their teacher writes a word on the board, but the student on the chair will not see it. Each team will have one minute after signaling the beginning of the game. Other students give description so that their seated teammate can guess the written word on the board. They should not say the exact written word on the board (Bakhsh, 2016).

Memory box: is another game that could be used to teach vocabularies for young learners. Students have to sit in pairs or form small groups. Each group is given three minutes to write down as many words as they can remember from their previous lesson (e.g. animals) and put them in a box. The group that recalls most words will win the game (Bakhsh, 2016).

'Last One Standing': The teacher gives a topic to the children (e.g. fruit). They have to stand up in a circle and the teacher counts to three and gives out the topic. After that, the first student in the circle has to give a word related to the topic and so on. The student who cannot say a new word or repeat the words of the last student has to take a seat. The last student standing will declare who is the winner (Bakhsh, 2016).

'Bingo.': In this game, the teacher writes 10 words on the board and every student chooses five words and writes them down. After that, the teacher chooses one word randomly without saying it and gives the students its meaning or synonym. If a student guesses the right word, he or she should shout BINGO! and wins the round (Bakhsh, 2016).

Drawing pictures: Teacher gives students a set of words about specific topic like nature, and the students have to draw a picture containing these words. (The researchers' own idea).

Slice of pizza: Teacher asks students to make a pizza that contains words related to a specific topic. For example, vegetable pizza contains words of vegetables written on pizza's slices. (The researchers' own idea).

It is significant here to stress the importance of using games in teaching vocabulary. First, using games in teaching is a useful and effective method because it attracts students' attention and encourages them to communicate and be active (Chan, 2000). Second, the significance of using games comes from the ability of games to give students a real chance to communicate with their teachers and with each other, while it decreases the levels of stress in the class (Deesri, 2002). Third, in case the ideas are not clear and understandable or organized well by using the traditional methods, the most appropriate solution is using games to make ideas clearer. In addition, using games helps students to organize their thoughts (Schmitt et al., 2017). Fourth, there are many factors which affect the process of achieving goals in teaching. For example, the goals of games must be proportionate with students' age and their abilities; they must help students to think, notice, observe, and compare, and they must be limited with a certain time (Kim, 1995). Fifth, Krashen (2001) argues that "learners with high motivation generally do better, and learns self-confidence, and a good self-image tends to be more successful"(p.183). Sixth, the main benefit of using games in teaching is creating an atmosphere of meaningful communication because it encourages students to communicate 
before, during, and after the game (Wright et al., 2005). Seventh, using vocabulary games encourages students to use the language (Lewis and Bedson, 1999). Eighth, students will get the chance to express their thoughts and feelings by using games in order to develop their creative language skills (Halliwell, 1992). Ninth, using vocabulary games decreases the nervousness and shyness of students and that positively affects students' performance (Richard-Amato, 1988, and Uberman, 1998). Tenth, it creates an interesting, fun, and comfortable environment, which make students retain words faster and better (Uberman 1998). Eleventh, games have a large effect on the learning process because they change a boring lesson into a fun and exciting journey which leads students to explore themselves (O'Riordan and Kirkland, 2010). Twelfth, it gives student the opportunity to be an active part in a significant competition which enhances students to use vocabulary effectively (Calhoun,1980).

The present study is based on a theoretical implication related to the positive effects of physical activities on cognitive outcomes. Learning by using games is based on the theory of Brain -based Learning which states that moderate to vigorous physical activity effectively encourages the brain in two terms. In short-term, it leads to biochemical changes in cerebral regions which leads to increase the attention and improve the cognitive performance. On the other hand, in the long-term it fosters angiogenesis, neurogenesis, and synaptogenesis in brain areas that are important for brain process as learning and memorizing (Vanderwolf and Cain, 1994).

Electrophysiological studies, neuropsychological tests and the use of imaging techniques have provided opportunities for researchers in the structural and functional studies of the human brain, which have provided evidences resulting in big changes for the field of education by understanding how the brain works (Cameron, 2001).

Brain based learning associates learning with the brain and the way it works, and this approach emphasized the positive effects of the brain's features and its enhancing performance on learning. In addition, the neuroscience, especially with the improvement of the magnetic resonance imaging, has proved that increasing physical activities effectively affects the neural system of the brain and that leads to develop the cognitive behaviors (Caine and Caine, 1997).

The discoveries in the cognitive science have revealed that the human brain physically changes when it learns, and that after practicing certain skills, because they become simpler to learn and to improve these skills (Vanderwolf and Cain, 1994). That means using games in learning vocabulary is an effective method, because it provides learners with a set of physical activities, which lead to improve the student's academic behaviors (Kruger, 2018).

It is well-proven fact that students face a lot of obstacles in learning a foreign language like English. Firstly, the most difficult issue in learning a foreign language is vocabulary, because students have to learn a large number of words to be able to use the language fluently. Secondly, the traditional method of learning vocabulary suffers from many shortcomings (see below) that have made quite ineffective. 


\section{Mll Macrothink}

International Journal of Linguistics

ISSN 1948-5425

2021, Vol. 13, No. 5

The current study is distinguished from other studies conducted on this topic, because the participants of this study are Syrian refugees students, who face several problems in learning English as a foreign language. Firstly, students suffer from poverty due to emigration from their homes and their parents' workplaces. Secondly, students' parents are mostly uneducated and were not exposed to English as a foreign language, which means they can not help their children in learning English as a foreign language. Thirdly, poverty and restrictions imposed on refugees prevent them to take extra English courses that would improve their proficiency in this language.

This study is important for many reasons. First of all, it investigates the relationship between using games as a method of learning vocabulary and improving student's performance in remembering, explaining, and using vocabulary, because using games effectively improves the process of vocabulary learning and stimulate the interest of student in learning vocabulary. Using games in teaching vocabulary seeks to achieve learning goals, such as the promotion of basic interpersonal communication skills and cognitive academic proficiency. Second, the present study may help to fill the gap in literature on second language acquisitions by discussing the specific topic of vocabulary and games. Finally, the study may pave the way for other studies that may investigate other ways of fostering students' English vocabulary such as conversation and listening.

Studies on the importance of learning vocabulary have been conducted over the last few decades (Halliwell, 1992; Cameron, 2001; Lessard-Clouston, 2013; Rabadi, 2016). Regarding using games to learn vocabulary, Azriel et al. (2005) stated that "regardless of age or economic, ethnic, or social background, people understand the language of play". (p.9). Harmer (2008) asserted that using language games should be systematic because it requires teachers to plan for what they have to do and to provide students with necessary materials, and also teachers should provide students with the experiences which make the class more communicative and interesting. Moreover, Huyen and Nga (2003) and Uberman (1998) agreed that games create a comfortable and fun environment for students to feel relaxed and that leads them to learn and retain words better. In addition, Freeman (1989) pointed out that using games is affective because it simulates real life when it requires communication which encourages players to exchange ideas with each other and it allows them to take immediate feedback from their colleagues and their teacher.

Bakhsh (2016) investigated games as a tool in teaching English vocabulary to young learners in Saudi Arabia. The researcher used vocabulary games based on pictures and colors. Results proved that games are effective tools when devised to explain vocabularies and they make it easier to remember their meanings.

Shanahan et al. (2006) studied how to overcome apathy and classroom disconnection by students toward their courses. His study emphasized that students' apathy leads to poor performance in the learning process. In his study, he applied Karaoke Jeopardy game. The results suggest that implementation of that game improved students' performance, and that factors like games being related to learning goals, games being comprehensible and motivating to students, are essential for the success of the learning process. 
Akrimah (2017) examined using picturing games in teaching vocabulary to the first grade students. The results reveal that Pictionary game is an effective tool in learning vocabulary for children. Other studies that stressed the usefulness of games in learning vocabulary include, among many others, Darfilal (2016), Gruss (2016), Wulanjani (2016), and Marius (2018).

Despite the fact that these studies addressed the use of games in learning vocabulary, yet none of them sought to deal with this strategy to teach English vocabulary to a group of female refugee students belonging to low-income families and not truly motivated to learn English. The current paper undertakes this first of its kind task with regard to 30 female Syrian students at a school in Jordan.

\section{Method and Procedure}

Thirty female students from the sixth grade at a school in Ramtha were selected to take part in the study. They were all Arabic-speaking Syrian individuals aged around 12 years-old. The sample was divided into an experimental and a control group, each including fifteen girls. The experimental group was exposed to vocabulary games in order to solve problems facing learners in learning vocabulary, and the control group was exposed to traditional methods in learning vocabulary.

The duration of the study was four months. During it, participants were exposed to the 10 vocabulary games defined in the introduction: Crosswords, Scrabble, Taboo, Crazy eraser, Hot potatoes, Memory box, Last One Standing, Bingo, Drawing pictures, and Slice of pizza. These games were not randomly chosen; rather, only games that were deemed exciting, attractive and clear, and those which could enable students to communicate and be active participants were picked. Additionally, these games were chosen to ensure the variety of words that students need to be exposed to and because they contained words that students must learn at this age.

The statistical package for social sciences (SPSS) was used and statistical averages and standard deviations of pre-test and dimension measurements were calculated on study tools, and appropriate statistical analyses were then used.

In order to find out if students' vocabulary achievement can significantly increase after being taught by using vocabulary games, some procedures were followed. Initially, the ten vocabulary games listed in the introduction were selected according to a set of criteria. Then, a tryout test was prepared and administered in order to choose which items should be presented in the pretest and posttest. After that, the pretest was given to the control and experimental groups to determine students' vocabulary achievement before being taught through vocabulary games. The test consisted of eighteen paragraphs of the types of matching between the words with their pictures, filling the blanks with the correct words, and circling the words that are from the same category. Next, the treatment, which consisted of using vocabulary games for forty minutes a day, three days a week for four months, was conducted and given to the experimental group. In the meantime, the control group was taught using the traditional method of vocabulary learning. After the end of the treatment, the posttest was 
administered to find out students' vocabulary achievement after being taught through vocabulary games and by the traditional method. The items of this test were similar to those of the pretest. (See Appendix (2)). Finally, the data from the pretest and posttest were analyzed by using the Statistical package for social sciences (SPSS).

Around 150 words belonging to various fields were chosen based on the students' curriculum and the games used. These fields included items related to school, transportation, the city, names of countries and nationalities, life in the desert, animals, body parts, house and furniture, the weather, jobs and professions, vegetables and grains, and family members. For examples of such words, see Appendix (1).

To verify the parity of the study groups in the pre-test, according to the means and standard deviations, the pre-test studies sample performance on the purpose-designed achievement test is shown in Table 1.

Table 1. Means and Standard Deviations for the performance of the pre-study sample

\begin{tabular}{lll}
\hline Group & Mean & Standard deviations \\
Treatment (Games) & 9.25 & 0.874 \\
Control (Traditional) & 8.97 & 0.912 \\
\hline
\end{tabular}

The results in Table 1 show a virtual difference between the Means for the performance of the pre-test sample on the attainment test according to the teaching method; the (t-test for two Independent samples) was used to know the statistical significance of the virtual difference, as shown in Table 2 .

Table 2. T-test Independent Sample to compare the Means for the performance of the study sample on the achievement test, according to the educational unit

\begin{tabular}{|c|c|c|c|c|c|c|}
\hline $\begin{array}{l}\text { Learning } \\
\text { Strategy }\end{array}$ & Vocabulary & Mean & Standard deviations & $\mathrm{T}$ & D.F & Sig \\
\hline Games & & 9.25 & 0.874 & 2.241 & 29 & 0.583 \\
\hline Traditional & & 8.97 & 0.912 & & & \\
\hline
\end{tabular}

Table 2 shows that the value of $(\mathrm{T})$ of the Learning Vocabulary Strategy was (2.241) in statistical significance $(0.583)$ and it is greater than the level of statistical indication $(\alpha=$ $0.05)$, indicating that there is no statistical difference in the performance of the study groups on the achievement test.

In order to determine the suitability and validity of the test items, the test was conducted with a separate study sample which included (15) female students. Then, both the Difficulty Index and Discrimination Index were calculated for each of the test items. Results showed that the Difficulty Index for the test items ranged between (0.45-0.84) while the Discrimination Index values were between (0.47-0.90). These results indicate that the test items are suitable and valid and that the test is acceptable for the purposes of the current study. 
Since the study contained one independent variable, the design of the study was a semi-experimental one based on an experimental group, a control group, pre measurement and telemetry, and the elements of the study design can be represented as follows:

1. EG: O1X1 O2

2. $\mathrm{CG}: \mathrm{O} 1-\mathrm{O} 2$

Where:

- EG: Experimental group of female students acquiring English vocabulary through playing Games.

- CG: The control group of female students studying in the traditional way.

- O1: The pretest.

- O2: The posttest.

- X1: Vocabulary games.

\section{Findings and Discussion}

Table 3 below presents the results of the posttest and pretest of vocabulary learning for both the experimental and control groups.

Table 3. Pretest and posttest of apparent difference between the pre and posttest Mean of the performance of the experimental group students who studied using Games Strategy on Learning Vocabulary

\begin{tabular}{lllll}
\hline Learning & Vocabuli & Post Test & \multicolumn{3}{c}{ Pre Test } \\
\cline { 2 - 5 } Strategy & Mean & standard deviation & Mean & standard deviatic \\
\hline Games & 16.25 & 0.97 & 9.25 & 0.874 \\
Traditional & 13.14 & 1.07 & 8.97 & 0.912 \\
\hline
\end{tabular}

According to the results of the tests in the table, there is a clear difference between the pre and posttest Performance Means of the experimental students who learned vocabulary through Games. The results also show that there is a clear difference between the posttest's results between the control and experimental groups, in favor of the experimental one. In order to find out whether these apparent differences are statistically significant, the accompanying one-way analysis of variance was used (One-way ANOVA) for post-measurement in the achievement test. Table (4) shows the results of the One=Way Anova:

Table 4. Post-measurement in the achievement test according to the Games Strategy on Learning Vocabulary

\begin{tabular}{lllllllllll}
\hline $\begin{array}{l}\text { Source } \\
\text { Variance }\end{array}$ & of & $\begin{array}{l}\text { Sum } \\
\text { squares }\end{array}$ & of & $\begin{array}{l}\text { Degrees } \\
\text { freedom }\end{array}$ & of & $\begin{array}{l}\text { Mean } \\
\text { squares }\end{array}$ & of $F$ & & Sig & ETA box \\
$\eta 2$
\end{tabular}




\begin{tabular}{lllllll}
\hline the group & 114.14 & 1 & 114.14 & 59.078 & 0.017 & 0.952 \\
The error & 54.12 & 28 & 1.932 & & &
\end{tabular}

Total $\quad 168.26 \quad 29$

The results in Table 4 show that there is a statistically significant (0.017) difference between the experimental group, that was taught through vocabulary games, and the control group, that was taught by using traditional method in learning English vocabulary, in favor of the experimental group. The figures also show that the size of the effect was large as it reached (0.952), which means that there is a significant effect in learning vocabulary of the English language attributed to the games method.

To determine the benefit of what was attributed, the arithmetic averages and their standard deviations were extracted according to the group, as shown in Table 5:

Table 5. Means and standard deviations on reflective thinking according to the designed unit (Games strategy, Traditional strategy)

\begin{tabular}{lll}
\hline Learning Vocabulary Strategy & Posttest Mean & standard deviation \\
\hline Games & 16.25 & 0.97 \\
Traditional & 13.14 & 1.07 \\
\hline
\end{tabular}

The results in Table 5 show that the difference was in favor of the experimental group who were exposed to the Learning Vocabulary Strategy designed by means of games.

The findings above clearly suggest that using vocabulary games is an effective method in providing fun and humor during the learning process: it contributes to collecting a large amount of information through the games. The present study further confirms the effectiveness of using vocabulary games in English language teaching and students' vocabulary learning, because it encourages students to be active participants in the process of learning vocabulary. The study has found that the memory box game has a positive effect on gaining information and vocabulary, and this finding agreed with Alshawi (2014) who demonstrated the strong effect of using games to make students more active, interactive, and gain a lot of skills and vocabulary. In addition, the present study results agree with Bakhsh (2016), who also shows that using games is very beneficial to learn vocabulary, because this strategy creates a comfortable atmosphere to learn, especially for young learners.

The study's quantitative findings clearly show that the experimental group's vocabulary improved more than that of the control group following the four-month treatment. The results reflect a remarkable improvement of the experimental group's performance in learning and using vocabulary. These results agree with Senol (2008), who affirms that using vocabulary games is more effective than the traditional methods, because the experimental group members have greater motivation to learn vocabulary than the control group members. 
However, the present study disagrees with Rohani and Pourgharib 's study (2013), which indicates that there are no significant differences between using vocabulary games and traditional methods in learning vocabulary.

The current findings also suggest that the students were more happy learning vocabulary through games. They complained much less than the students of the control group who regarded learning vocabulary through traditional methods as "no fun" and 'a lot of work". This agrees with Darfilal (2016), who indicates that the students were happy to play the games and to be in an activity where they can interact with each other. Indeed, it could be observed by the researchers that everyone in the classroom wanted to participate to the games, and that the students had a positive attitude toward games, which had a great effect on students' results in learning vocabulary.

The present study's results agree with findings by other studies on using games to learn vocabulary. For example, they confirm findings by Ramadhaniarti (2016), who indicated that majority of his $7^{\text {th }}$ grade students preferred playing vocabulary games, because they considered them more interesting and challenging and enabled them to retain new English words more easily. Furthermore, the current study results agree with Akrimah (2017), who also confirmed that using vocabulary games like the Pictionary game is an effective tool in learning English vocabulary for children, since it enhances students to be active and learn more vocabulary in order to be able to express themselves.

\section{Summary}

The current study examined the influence of using vocabulary games on learning English vocabulary, as opposed to the traditional methods of learning vocabulary. The sample of the study consisted of 30 Syrian refugee students at a school in Ramtha, Jordan. The sample was divided equally into an experimental (15 learners) and a control group (also 15 learners). A set of 10 vocabulary games was selected to help the experimental group acquire new vocabulary. Moreover, about 150 words related to school, furniture, body parts, and family members were used in pretests and posttests for both the experimental and control groups. The results of the quantitative analysis showed obvious differences between the experimental group, which was exposed to vocabulary games, and the control group, which was exposed to traditional methods, in favor of the experimental one. Thus, it can be further confirmed that using vocabulary games inside classrooms for second language learners is an effective method for developing vocabulary. So, teachers should be encouraged to practice vocabulary games in their classrooms in order to motivate students to learn more English vocabulary.

In light of these findings, it is suggested not only to encourage the use of games in learning vocabulary but to devise new games to do so. Moreover, further studies must be carried out in Jordan and other Arab countries on this same topic through using other games than those in the present study. In addition, studies on the impact of games on other language components such as pronunciation and speaking, expression and writing, spelling and grammar are recommended for all levels of school and college students. 


\section{Macrothink}

International Journal of Linguistics

ISSN 1948-5425

2021, Vol. 13, No. 5

The limitations of the present study are clear as it focuses only on a small group of Syrian refugee students in one Jordanian town and deals with the topic of vocabulary learning. Thus, the findings cannot be generalized to other groups of refugee students in Jordan and elsewhere. The paper, however, paves the way for other studies to be carried out on other students in areas that are crowded with refugees to deal not only with vocabulary learning but also with other language components like pronunciation and syntax.

\section{References}

Akrimah, R. Y. (2017). Teaching vocabulary through dictionary games to first grade of SMPN 1 way tuba. Doctoral dissertation, Lampung University, Malaysia.

Al-Shawi, M. A. (2014). Using game strategy for motivating students to learn new English vocabulary. AmarabacMagazin, 39(2232), 1-21.

Azriel, J., Erthal, M., \& Starr, E. (2005, Sept/Oct). Answers, questions, and deceptions: what is the role of games in business education. Journal of Education for Business, 9-13

Bakhsh, S. (2016). Using games as a tool in teaching vocabulary to young learners. English Language Teaching, 9(7), 120.

Brown, H. D. (2001). Teaching by principle: An interactive approach to language pedagogy. New York: Longman.

Brown, J. D. (2009). Foreign and second language needs analysis. The handbook of language teaching, (269).

Brown, R. (1973). A first language: The early stages. Cambridge: Harvard U. Press.

Caine, R. N., \& Caine, G. (1997). Education on the edge of possibility. Association for Supervision and Curriculum Development, 1250 N. Pitt Street, Alexandria, VA 22314-1453.

Calhoun, C. (1980). Managing the learning process in business education. Belmont, CA: Wadsworth Publishing Company.

Cameron, L. (2001). Teaching language to young learners. UK: Cambridge University Press. https://doi.org/10.1017/CBO9780511733109

Chen, C. F. (2007). Computer assisted language learning and teaching. Tourism management, 28(4), 1115-1122.

Cheng, H. P. (1988). Teaching English as a foreign language in China. TESL Canada Journal, 88-93.

Darfilal, I. (2015). The effectiveness of using language games in teaching vocabulary the case of third year middle school learners. Doctoral dissertation. Institutional deposit of the University AbouBekrBelkaidTlemcen UABT, Department of Foreign Languages.

Deesri, A. (2002). Games in the ESL and EFL class. The Internet TESL Journal, 8(9), 1-5. 


\section{Macrothink}

International Journal of Linguistics

ISSN 1948-5425

2021, Vol. 13, No. 5

Freeman, D. (1989). Teacher training, development, and decision making: A model of teaching and related strategies for language teacher education. TESOL Quarterly, 23(1), $27-45$.

Gruss, J. (2016). Games as a tool for teaching English vocabulary to young learners. World Scientific News, 53(2), 67-109.

Halliwell, S. (1992). Teaching English in the primary classroom. New York: Longman.

Harmer, J. (2008). How to teach English. ELT Journal, 62(3), 313-316.

Hatch, E., \& Brown, C. (1995). Vocabulary, semantics, and language education. Cambridge: Cambridge University Press.

Hornby, A. S. (1995). Oxford Advanced Learner's Dictionary. New York: University Press. Retrieved April 20, 2007, from http://www.nkfust.edu.tw/nemchen/CALL/

Huyen, N., \& Nga, K. (2003). Learning vocabulary through games. Asian EFL Journal, 5(1), $33-41$.

Krashen, S. D. (1985). Inquiries \& insights: Second language teaching: immersion \& bilingual education, literacy. Alemany Press.

Krashen, S. D. (1985). The input hypothesis: Issues and implications. New York: Longman.

Krashen, S. D. (2003). Explorations in language acquisition and use. (hardback: ISBN-0-521-47409-4; paperback: ISBN-0-521-47942-8.

Krüger, M. (2018). Second language acquisition effects of a primary physical education intervention: A pilot study with young refugees. PloS one, 13(9), e0203664.

Lessard-Clouston, M. (2013). Teaching Vocabulary. Alexandria, VA: TESOL International Association.

Lewis, G., \& Bedson, G. (1999). Games for children. New York: Oxford University Press.

Linse, C. (2005). Practical English language teaching: Young Learners. New York: McGraw-Hill.

Marius, E. P. (2018). Practical strategies 'to teach vocabulary through games in EFL beginner classes: The case study of some secondary schools in Abomey Region.

O'Riordan, F., \& Kirkland, D. (2008). Games as an engaging teaching and learning technique: Learning or playing. Novel Approaches to Promoting Student Engagement, 77.

Rabadi, R. (2016). Vocabulary learning strategies employed by undergraduate EFL Jordanian students. English Language and Literature Studies, 6(1), 47-56.

Ramadhaniarti, T. (2016). Teaching English vocabulary through game: Views from the students. Proceedings of ISELT FBS UniversitasNegeri Padang, 4(2), 382-387. 


\section{Macrothink}

International Journal of Linguistics

ISSN 1948-5425

2021, Vol. 13, No. 5

Richard-Amato, P. A. (1988). Making it happen: Interaction in the second language classroom: From theory to practice. New York: Longman.

Rohani, M., \& Pourgharib, B. (2013). The effect of games on learning vocabulary.

Saville-Troike, M. (1984). What really matters in second language learning for academic achievement?. TESOL Quarterly, 18(2), 199-219.

Schmitt, N. (2000). Vocabulary in language teaching. Cambridge: Cambridge University.

Schmitt, N., Cobb, T., Horst, M., \& Schmitt, D. (2017). How much vocabulary is needed to use English? Replication of van Zeeland \& Schmitt (2012), Nation (2006) and Cobb (2007). Language Teaching, 50(2), 212-226.

Şenol, M. (2008). Teaching vocabulary to secondary school students through games. Doctoral dissertation, SelçukÜniversitesiSosyalBilimlerEnstitüs.

Shanahan, K., Hermans, C., \& Haytko, D. (2006). Overcoming apathy and classroom disconnect in marketing courses: Employing Karaoke Jeopardy as a Content Retention Tool. Marketing Education Review, 16(1), 85-90.

Sweet, H. (1972 [1899]). The practical study of languages. London: Oxford University Press.

Tunchalearnpanih, P. (2012). Using games on P. 6 student's vocabulary learning. Thailand: Srinakharinwirot University (SWU).

Uberman, A. (1998). The use of games for vocabulary presentation and revision. Forum, $36(1), 20-27$.

Vanderwolf, C. H., \& Cain, D. P. (1994). The behavioral neurobiology of learning and memory: a conceptual reorientation. Brain Research Reviews, 19(3), 264-297.

Wallace, M. J. (1982). Teaching vocabulary (No. 10). Heinemann.Teachers: Toward a rationale. Washington, D.C.: Georgetown University

Webster, M. (1961). Webster third new international dictionary. Chicago: The University of Chicago. USA.

Wilkins, D. (1972). Linguistics in language teaching. London, UK: Arnold.

Wilkins, D.A. (1972). Linguistics in language teaching. Cambridge: MFT Press.

Wright, A., Betteridge, D., \&Buckby, M. (1992). Games for language learning. Ernst KlettSprachen. USA.

Wulanjani, A. N. (2016). The use of vocabulary-games in improving children's vocabulary in English language learning. Transformatika: JurnalBahasa, Sastra, danPengajarannya, 12(1), 76-83. 
Appendixes

\section{Appendix 1. List of Words}

\begin{tabular}{|c|c|}
\hline \multicolumn{2}{|c|}{ Words related to School } \\
\hline English Word & Meaning in Arabic \\
\hline School & مدرسة \\
\hline Bag & حقيبة \\
\hline Pencil & قلم رصاص \\
\hline Pen & قلم حبر \\
\hline Book & كتاب \\
\hline Rubber & 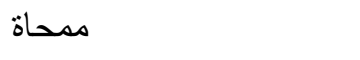 \\
\hline Be quiet & كن هادئ \\
\hline Board & سبورة \\
\hline Chair & 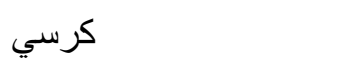 \\
\hline Class & غرفة صفية \\
\hline Teacher & 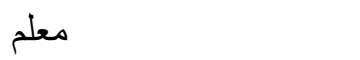 \\
\hline
\end{tabular}

Words related to transport

\begin{tabular}{|c|c|}
\hline Car & سيارة \\
\hline Plane & طائرة \\
\hline Train & قطار \\
\hline Cart & عربة \\
\hline Bus & حافلة \\
\hline Taxi & سيارة أجرة \\
\hline Ship & سفينة \\
\hline Boat & قارب \\
\hline Motorcycle & در اجة نارية \\
\hline Bicycle & در اجة \\
\hline Van & شاحنة صغيرة \\
\hline
\end{tabular}


Words related to the city

\begin{tabular}{ll}
\hline Buildings & بنايات \\
Tower & جرج \\
Bridge & شوق طريق \\
Market & مطعم \\
Road & Street \\
\hline
\end{tabular}

Names of countries and their nationalities

\begin{tabular}{|c|c|c|c|}
\hline Name of country & Meaning & Nationality & Meaning \\
\hline Jordan & الأردن & Jordanian & اردني \\
\hline Syria & سوريا & Syrian & سوري \\
\hline Lebanon & 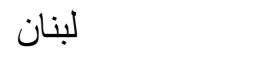 & Lebanese & 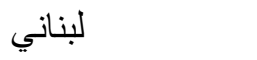 \\
\hline Egypt & مصر & Egyptian & مصري \\
\hline Saudi Arabia & السعودية & Saudi Arabian & سعودي \\
\hline
\end{tabular}

Words related to the desert

\begin{tabular}{|c|c|}
\hline Desert & صحر اء \\
\hline Mountain & جبل \\
\hline Valley & و ادي \\
\hline Tent & خيمة \\
\hline Rocks & حجارة \\
\hline Sand & رمل \\
\hline
\end{tabular}

Words related to animals

\begin{tabular}{ll}
\hline Animals & حيو انات \\
Cow & بقرة \\
Cat & خروف \\
Birds & اسدر \\
Sheep & Lion \\
\hline
\end{tabular}


Tortoise

Camel

Deer

Horse

Snake
سلحفاة
جمل
غزال
حصان
أفعى

Words related to parts of body

\begin{tabular}{|c|c|}
\hline Head & رأس \\
\hline Ear & أذن \\
\hline Neck & رقبة \\
\hline Eye & عين \\
\hline Nose & أنف \\
\hline Mouth & فم \\
\hline Arm & ذراع \\
\hline Shoulder & كتف \\
\hline Hand & يد \\
\hline Wrist & رسغ \\
\hline Finger & اصبع \\
\hline Leg & رجل \\
\hline Foot & قدم \\
\hline Toe & اصبع القدم \\
\hline
\end{tabular}

Words related to furniture

\begin{tabular}{|c|c|}
\hline Television & ت تلفاز \\
\hline Washing machine & غسالة \\
\hline Clock & ساعة \\
\hline Microwave & المايكرويف \\
\hline Cooker & غاز \\
\hline Sofa & كنبة \\
\hline Telephone & تلفون \\
\hline Lamp & مصباح \\
\hline Picture & لوحة \\
\hline
\end{tabular}


Armchair

Coffee table

Cushion

Curtain

Wardrobe

Desk

Bed

Bookcase

Rug

Chair

Shower

Toilet

Fridge
كرسي ذو ذراعين

طاولة قهوة

وسادة

ستارة - - من

خز انة

مقعد

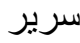

خز انة الكتب

سجادة/بساط

مقعد

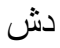

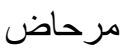

ت تلاجة

Words related to weather

\begin{tabular}{|c|c|}
\hline Weather & الطقس \\
\hline Hot & حار \\
\hline Warm & دافئ \\
\hline Cold & بارد \\
\hline Sunny & مشمس \\
\hline Rain & مطر \\
\hline Snow & ثلج \\
\hline Thunder & رعد \\
\hline Wind & رياح \\
\hline Fog & ضباب \\
\hline Freeze & صقيع \\
\hline Cloudy & غائم \\
\hline
\end{tabular}




\section{Words related to jobs}

\begin{tabular}{|c|c|}
\hline Jobs & وظائف \\
\hline Teacher & معلم \\
\hline Doctor & طبيب \\
\hline Baker & خباز \\
\hline Pilot & طيار \\
\hline Policeman & شرطي \\
\hline Nurse & ممرض \\
\hline Farmer & مزارع \\
\hline Driver & سائق \\
\hline Lawyer & محامي \\
\hline Engineer & مهندس \\
\hline
\end{tabular}

Words related to vegetables

\begin{tabular}{|c|c|}
\hline Vegetables & خضروات \\
\hline Tomato & بندورة \\
\hline Potato & بطاطا \\
\hline Carrot & جزر \\
\hline Cucumber & خيار \\
\hline Lettuce & خس \\
\hline Eggplant & باذنجان \\
\hline Onion & بصل \\
\hline Lemon & ليمون \\
\hline Corn & ذرة \\
\hline Cabbage & ملفوف \\
\hline
\end{tabular}

Words related to family members

\begin{tabular}{ll}
\hline Family & عائلة \\
Father & أب \\
Mother & أُ \\
Sister & $\dot{C}^{\prime}$ \\
Brother & $\dot{C}^{\prime}$ \\
\hline
\end{tabular}




\section{Macrothink}

\begin{tabular}{|c|c|}
\hline Uncle & عم_خال \\
\hline Aunt & عمة _خالة \\
\hline Grandpa & جد \\
\hline Grandma & جدة \\
\hline Husband & زوج \\
\hline Daughter & ابنة \\
\hline Son & ابن \\
\hline Wife & زوجة \\
\hline Child & طفل \\
\hline
\end{tabular}

Appendix 2. Test Improvement of English Performance

Vocabulary test 2020/2019

Name: 


\section{Macrothink}

Question number one: match these words with the related pictures:

1. horse

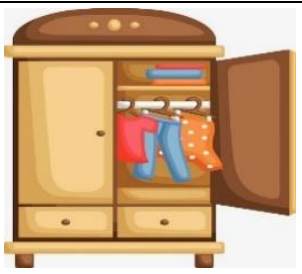

2.wardrobe
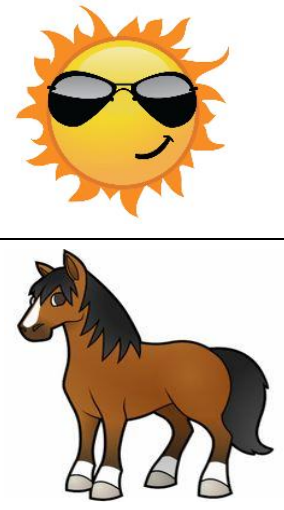

3.train

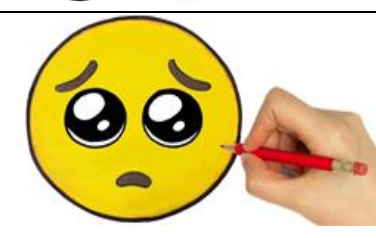

4.sunny

5.running

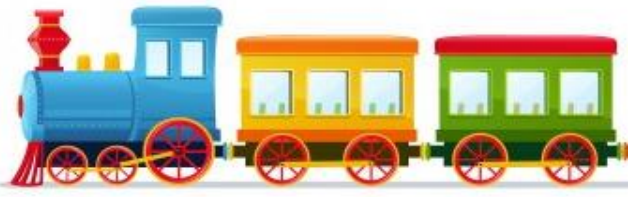

(4) ${ }^{3} 2^{2}$

6.sad

(5) (1)

7.fingers

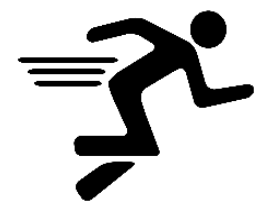


Question number two: fill in the blanks with appropriate words:

\section{Plane, Jordan, carrot, teacher, hands, crying}

1. the baby is

2. I traveled to America by

3. I live in

4. I like salads with

5. is who teaches us.

6. You should wash your before eating.

Question number three: Circle three words related to each of the following:

\section{a. transportation:}

head, snow, lamp, pilot, taxi, car, chair, birds, ship.

\section{b. body parts:}

tower, sand, head, afraid, foot, desk, mouth, rain.

\section{c. house and furniture:}

snow, toilet, cold, leg, lamp, walking, bed, bridge, farmer.

\section{d. jobs:}

student, farmer, sheep, van, policeman, train, doctor, brother.

\section{e. school:}

cold, corn, bag, rubber, farmer, uncle, book, head, toe.

\section{GOOD LUCK}




\section{Copyrights}

Copyright for this article is retained by the author(s), with first publication rights granted to the journal.

This is an open-access article distributed under the terms and conditions of the Creative Commons Attribution license (http://creativecommons.org/licenses/by/4.0/) 